\title{
Suulisus kirjakultuuri ajajärgul ${ }^{1}$
}

\author{
Tiiu Jaago \\ Tartu Ülikooli kultuuriteaduste instituudi \\ eesti ja võrdleva rahvaluule osakonna dotsent \\ tiiu.jaago@ut.ee
}

\begin{abstract}
Teesid: Suulisuse ja kirjalikkuse teema folkloristikas on mitmetasandiline ja jätkuvalt aktuaalne. Ühelt poolt on tegemist teoreetilise kontseptsiooniga, kuna ajalooliselt on suulisus üks rahvaluule määratlemise keskseid tunnuseid. Samas on suur osa suulisest pärimusest kättesaadav üleskirjutuste kaudu. See seob suulise pärimuse kirjakultuuriga: mitte ainult jäädvustusviisi tõttu, vaid eriti tekstiarhiivi korrastamise, süstematiseerimise ja publitseerimise kaudu. Teisalt on tegemist uurimispraktiliste küsimustega: mil määral on vaja suulise pärimuse uurimises arvestada selle suulisust?; mil määral ja milliste rahvaluuleliikide puhul ei ole suulisus rahvaluule määravaks tunnuseks ja kuidas see mõjutab folkloristliku teooria ning teadusajaloo mõistmist?; milles ilmnevad teoreetiliste ja uurimispraktiliste aspektide seosed ja lahknevused? Artiklis keskendutakse neile teemadele eesti folkloristika näitel.
\end{abstract}

Märksõnad: rahvaluule, suuline ajalugu, suuline kirjandus, suulisus

Artikkel on pühendatud rahvaluule suulise ehk kuuldava ja kirjaliku ehk nähtava esituse omavahelistele seostele. Eesmärk on näidata, kuidas suulisus ja kirjalikkus ei pruugi alati olla mõistetavad kui kaks teineteisele järgnevat või vastanduvat nähtust. Folkloristika ajaloos on perioode, kus suulisuse ja kirjalikkuse vastandus tuleb selgelt esile, siis aga see taandub, sõltudes üldisemast uurimisfookusest ja selle ümberpaiknemisest. Täpsemal vaatlusel ilmneb, et hoolimata sellest, milline on hetkel domineeriv arusaam, on suulisus ja kirjalikkus folkloristika eri tasanditel paralleelselt olemas. (Kõnelemata rahvaluule enda esinemisviiside mitmekesisusest.) Eri tasandite all võib silmas pidada nii teooria ja teaduspraktika omavahelisi seoseid ja lahknevusi kui ka erinevusi rahvaluuleliikide käsitlemisel.

Järgnev vaatlus jaotub kolmeks alateemaks: teooriatasand ehk suulisuse osakaal rahvaluule defineerimisel; teaduspraktika tasand ehk suulisus rahvaluule uurimisel; rahvaluule koht sellistes kontseptsioonides nagu suuline kirjandus ja suuline ajalugu. 


\section{Suulisus rahvaluule definitsioonis: käsitluse lähtepunkt}

Rahvaluule üks esiletoodumaid tunnuseid on olnud rahvaluule suulisus. Selle üheks (esmaseks) põhjuseks on arusaam rahvast. Folkloristika kujunemisajal 19. sajandil määratleti rahvast (kelle luulet, kombeid, lugusid, elu vms folkloorina uuriti) ühiskonna sellise elanikkonnakihina, kes eristus kirjaoskamatuse poolest haritud eliidist. 1977. aastal avaldatud ja folkloristika klassikasse kuuluvas artiklis "Kes on rahvas?" kirjeldab Alan Dundes seda olukorda nii: "Kuivõrd rahvast defineeriti eelkõige vastavalt tema oletatavale suhtele tsiviliseeritud inimeste ehk eliidiga, siis eelduste kohaselt eksisteeris rahvaluule ainult seal, kus oli ka tsivilisatsioon või eliit" (Dundes 2002: 14). Seega: rahvaluulet ei seostatud mitte kirjaeelse suulise kultuuriga, vaid nimelt suulise ja kirjaliku kultuuri omavaheliste seostega kirjakultuuri-ühiskonnas. Oluline on ka eeltsiteeritud väites kahe elanikkonnakihi (kirjaoskamatu rahva ja kirjaoskusega eliidi) suhte esiletõst rahvaluule mõiste kujunemises. Just selles väites sisaldub rahvaluule defineerimise ajaloo üks lähtepunkte: rahvaluule on suuline, vastandudes haritud inimeste kirjakultuurile. Sellele tugineb ka vastandus rahvaluule kui suuline looming ja kirjandus kui kirjakultuuri ilming.

Alan Dundese eelviidatud käsitlus haakus 1960.-70. aastatel Ameerikas toimunud rahvaluuleteadust uuendanud aruteludega, kus filoloogia raames väljakujunenud tekstikeskse folkloristika kõrval kõneldi üha enam pärimuse kontekstidest, kommunikatiivsusest, esituslikkusest (vt nt Gabbert 1999; Bronner 2016). Päevakorda tuli nn tänapäeva folkloor, mis hõlmas 20. sajandi ühiskonda iseloomustavaid rahvaluulevorme. "Rahvast" hakati vaatlema kultuuriliselt seotud väikerühmadena (Alan Dundese järgi siis senise talurahva asemel vähemalt üht ühist tunnust omava inimeste rühmana). Eriti nähtavale tulid rahvaluule esituse uuringud (performance): kui filoloogiasuunalises folkloristikas vaadeldi ka pärimusteksti fikseeritud "kirjandusliku artefaktina", siis performance'i-käsitluses asetus rõhk pärimusteksti jätkuvale loomisprotsessile selle esitustes (Bauman 2012: 103; vt kaVõsu 2008; Bronner 2016: 8; vt eesti kontekstis rahvaluule esituslikkuse esiletõusu: Rüütel 1987: 13-14). 21. sajandi algul suunduvad rahvaluule määratlemise otsingud ühitama kirjeldatud arusaamu digiajastu-omaste uuendustega. Näiteks Simon J. Bronner näeb rahvaluule tänapäevase defineerimise võimalusi selles, et rõhutada traditsiooniliste teadmiste (mitte nt kunstiliste tekstide vms) jätkuvat kasutamist oma igapäevases elus, sh ka digitaalses keskkonnas (Bronner 2016).

Kuidas on need uuenenud, pärimustegevust ja -toimimist rõhutavad käsitlused folkloristikas mõjutanud arusaama rahvaluule suulisusest ja kirjalikkusest? Mida enam huvitub folkloristika pärimusrühmast kui kultuuriliselt seotud 
inimeste rühmast ning selle rühma raames toimuvast eripärasest kommunikatsioonist, seda enam eemaldub suulisuse nõue rahvaluule määratlusest. Näiteks kontekstikeskse folkloristika kujunemisloos olulist rolli mänginud 1971. aastal ilmunud artiklis "Folkloori defineerimine konteksti kaudu" kritiseerib Dan Ben-Amos rahvaluule olemuslikele tunnustele (rahvaluule kollektiivsus, traditsioonilisus, suulisus) üles ehitatud definitsioone: "Kui kollektiivse loomise teooriad kokku varisesid ja säilmete doktriin läbi kukkus, said teadlased kindlaks jääda ideele, et folkloor on suuline kunst, kirjalikult jäädvustamata mentefaktid ja suuliselt edasiantud kirjandus" (Ben-Amos 2009: 15-16). Selles tsitaadis on muuhulgas viide rahvaluule käsitlemisele suulise kirjandusena, millest tuleb pikemalt juttu allpool. Ben-Amos defineerib rahvaluulet järgmiselt: "Kokkuvõttes on folkloor väikeses rühmas toimuv kunstiline kommunikatsioon" (Ben-Amos 2009: 21). Kuidas ta põhjendab suulisuse väljajätmist rahvaluule definitsioonist? See on lihtne: suulisuse nõue piirab rahvaluule nägemist ja mõtestamist tänapäeva ühiskonnas, sest tegelikkuses tekstid ja esitusviisid põimuvad. Ka ei näe Ben-Amos põhjust kõrvaldada folkloristide huviväljast suuliselt ringlevaid, ent trükiallikast mõjutatud lugusid (s.o ta ei sea rahvaluule piiritlemise tingimuseks selle suulist algupära), samas aga “[---] lakkab televisioonis esitatud või trükis ilmunud laul, jutt või mõistatus olemast folkloor, kuna muutunud on selle kommunikatiivne kontekst" (Ben-Amos 2009: 23). Tänapäeva vaatepunktist võib see väide mõjuda äärmuslikuna: kas uus kommunikatiivne kontekst välistab igal juhul rahvaluuleks olemise? Ka trükistes, massiteabevahendites, reklaamis jms avaldatud rahvaluule võib olla äratuntav nimelt rahvaluulena. Ja vastupidi: mitmetes harjumatutes keskkondades, sh nt sotsiaalmeedias, ajakirjanduses vms avaldatu ei pruugi pärimusrühma olemasolugi korral olla teadvustatud kui rahvaluule (folkloor, pärimus). Hilisemates teoreetilistes aruteludes on rahvaluulet käsitletud protsessina, kus võib eristada rahvaluule mitmeid kultuuris ilmnemise ja olemasolemise viise (vt nt Honko 1990). Uurimisse on see kaasa toonud vajaduse arvestada uuritava rahvaluule esinemisseost (ilmnemise, jäädvustamise, talletamise vms kontekste). Oluline on antud juhul ka see, et kontekstikeskse folkloristika seisukohtade arvestamine suunas enam tähele panema ja välitöödel jäädvustama mitte ainult teksti, vaid ka selle esitusega seonduvaid nii situatiivseid-hetkelisi kui ka üldkultuurilisi raame (Bronner 2006: 226).

Folkloristika-ajaloolisest ekskursist ilmneb, et suulisuse nõue rahvaluule määratlemisel taandub seda enam, mida enam mõistetakse rahvaluulet "omaette suhtlemissfäärina”, nagu selle sõnastab Ben-Amos. Kui rõhk rahvaluule piiritlemisel asetub kommunikatiivsusele, ei mineta see rahvaluule seotust suulise esitusega, ent sellega koos tunnustatakse teisigi pärimusvahenduse viise (nt kirjalikke, pildilisi, viipelisi vms). Teaduspraktikas on aga küsimus 
suulisuse ja kirjalikkuse omavahelistest seostest jätkuvalt esil. Kuid nüüd nihkub küsimuseasetus rahvaluule (kui suulise kultuuriilmingu) piiritlemiselt suulisuse ja kirjalikkuse omavahelistele seostele, seda nii rahvaluule enda kui ka selle uurimise vaatepunktist.

\section{Eesti rahvaluule ja selle uurimine: kirjakultuuri vaatepunkt}

Rahvaluule defineerimine suulise päritolu, leviku ja esituse kaudu taandus eesti folkloristikas 1980. aastatel, kui suulisuse asemel hakati rõhutama pärimuse kommunikatiivsust ning pärimuse esituslikkuse ja paindliku muutumise osatähtsust folklooriprotsessis (vrd Laugaste 1986: 50-52 vs. Rüütel 1987: 13-14; Jaago 1999; Valk 2005a: 11; Kuutma 2010). ${ }^{2}$ Ometi ei taanda see suulise ja kirjaliku teema olulisust folkloristikas. Miks? Enamik eesti rahvaluule uurimisallikaid on kirjalikud, see tähendab - need on suulise esituse kirjapanekud. Selles mõttes on taas oluline rõhutada rahvaluuleteaduse algusajale omast kirjaoskuseta rahva ja haritud eliidi omavahelist seotust: just haritud eliit oli see, kes määras, mida rahvaluulena kirja pandi. Kontekstikeskse folkloristika seisukohast muutub oluliseks küsimus, mille poolest erineb rahvaluule selle loomulikus elukeskkonnas ja pärast rahvaluule kirjapanemist, kuna neis ülekannetes pärimuse kontekst muutub. Teisisõnu: kuidas muudab suulise teksti dokumenteerimine teksti analüüsimise võimalusi? Küsimus ei seisne seega mitte vastanduses (kas tekst või kontekst), vaid teksti ja konteksti(de) omavahelistes mõjuseostes.

Rahvaluuletekstide dokumenteerimise viisist ja eesmärkidest lähtuvalt jaotatakse Eesti folkloristika kaheks ajalooliseks perioodiks: rahvaluuleteaduse eelne ja rahvaluuleteaduslik periood. Esimest iseloomustab rahvaluuletekstide juhuslik, teist sihipärane kirjapanek (Laugaste 1963: 5-6). Siit lähtub kontekstikeskse folkloristika seisukohast üks vastuolu: juhuslikud kirjapanekud võivad sisaldada enam teavet selle kohta, kuhu rahvaluule kultuuritervikut silmas pidades paigutus, samas kui sihipärased üleskirjutused vormistati ja süstematiseeriti kirjakultuurist pärit abstraktsete skeemide järgi, milleks on rahvaluuleliigid (nt laulud, jutud, lühivormid jms). Folkloristikas eristatavad liigid (või žanrid) on ka rahvaluule loomulikus esituses olemas, ent uurimise tarvis oli tekstide kogumise ja arhiveerimise käigus vaja suulises käibes olnud žanr jaotada osadeks, näiteks lauludest eraldus muusika- ja sõnaosa. Laulude esitamiskontekst võib esile tulla näiteks temaatilis-funktsionaalses liigituses (pulmalaulud, itkud), kuid otsest seost esitusolukordade ja sõnalise teksti vahel ei pruugi arhiivis talletatud materjalist leida. ${ }^{3}$ Ka tekstianalüüsimeetodid 


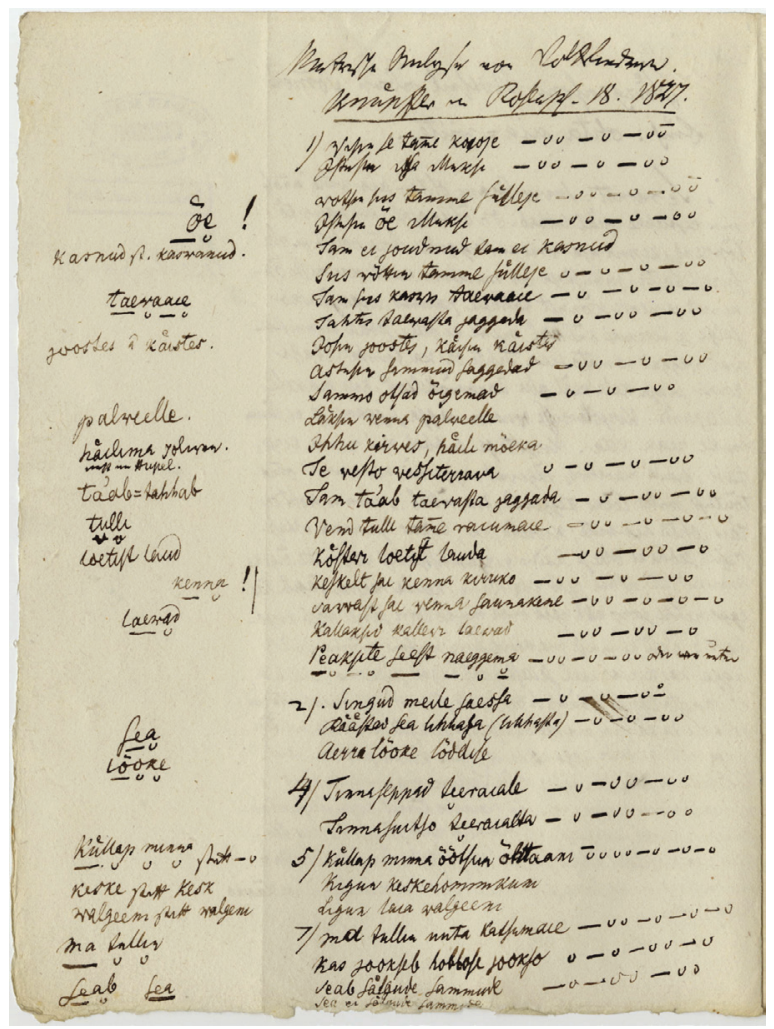

Näide Fr. R. Faehlmanni regilaulu värsimõõdu analüüsi sisaldavast käsikirjast Õpetatud Eesti Seltsi kogust. EKLA, ÕES MB 9:30, lk 2.

lähtusid kirjakultuurist, mõeldagu kasvõi regilaulu poeetika analüüsile, kus nii hääliku- kui sõnakordused, nagu ka värsimõõt on analüüsitavad nähtavate (mitte kuuldavate) skeemidena.

Ilmneb, et rahvaluule dokumenteerimine uurimise tarvis eeldas selle kirjas jäädvustamist. Tänapäeva folkloristika seisukohast muudab suulise esituse ülekanne kirjalikuks ka teksti (nähtuse) tõlgendusraame. Seda kirjeldatakse mh ka intertekstuaalsuse mõiste kaudu: pärimusteksti mõjutab see, milline on teksti suhe teiste teda ümbritsevate tekstidega. Ülo Valk osutab näiteks muistendi intertekstuaalsele taustale: kui muistend üle kanda suulisest pärimusest trükiteksti vm “[---] võib uus diskursiivne ja ideoloogiline kontekst muuta žanri staatust, ülendades seda väärtuslikuks muinaspärandiks või vastupidi - alandades kui arutu ebausu väljendust" (Valk 2015: 542). Intertekstuaalsuse mõiste suunab rahvaluulet vaatlema ja tõlgendama, arvestades selle esinemiskonteksti mõju pärimuse mõtestamisele. Ühtlasi tõstatub küsimus žanri mõiste muutumisest 20. sajandi teise poole folkloristika uuenemise käigus. 
Kontekstikeskse folkloristika seisukohast võiks näha teatavat vastuolu rahvaluule määratlemise ja rahvaluule žanrilisuse vahel. Ühelt poolt võivad rahvaluuletekstid oma kasutusseostest lähtuvalt kaotada küll oma pärimusloomuse (Ben-Amose järgi lakkavad folkloorist pärit tekstid olemast pärimustekstid, kui neid esitatakse televisioonis vm väljaspool pärimusrühmale omast kommunikatsioonikeskkonda), ent teisalt jääb nende tekstide žanrilisus erinevates kasutusseostes püsima. Näiteks vanasõnade kasutamine ruumikujunduses, reklaamis vm ei kaota vanasõnade žanriidentiteeti, kuigi need ei esine enam pärimuse nn loomulikus kontekstis ega ole seetõttu Ben-Amose sõnastatud kontekstikeskse folkloristika vaatepunktist käsitletavad rahvaluulena. (Küll võib neid vaadelda kui rahvaluule-elementide kasutamist muudes kultuurivaldkondades.) Sellist rahvaluule žanri stabiilsust (kus ei saa täiel määral arvestada pärimusteksti kasutusseost) toetab tekstikeskne žanriteooria, mille järgi žanrit käsitletakse "kui tekstuaalset väljendusviisi" ja kus žanrimääratluse aluseks on "konkreetsed tekstitunnused" (Org 2017: 24). See lähenemisviis seob folkloristika kirjandusteadusega (ja ühtlasi kirjalike tekstidega) ning peaks sobituma hästi eesti folkloristikasse, mille tuumaks on suur rahvaluule kirjapanekute arhiiv. Sellegipoolest on ilmne, et pärimuse kommunikatiivsusest lähtuva rahvaluule defineerimisega pidi kaasnema ka žanri mõiste uuenemine.

Tänapäeva folkloristlikud žanriteooriad võimaldavad vältida vastuolu fikseeritud teksti ja loo esituse vahel, kuna žanri määratlemisel võetakse arvesse teksti kasutusseosest tulenevat tähendusloomet ning esitust ja esitusolukorda vaadeldakse kui konkreetse teksti (variandi) loomise mõjuvälja. Seega žanrit ei piiritleta mitte ainult teksti tunnuste abil, vaid küsitakse ka, kuidas esitusolukord on mõjutanud vaadeldava (fikseeritud) teksti just seesugust korrastatust (vt nt Bauman 2012: 103; vrd Frog \& Koski \& Savolainen 2016: 23; Org 2017: 37). Mõistagi sobib selline lähenemisviis tänapäevaste folklooriliikide kirjeldamiseks, kus välitöödel pööratakse tähelepanu esitusega seotud andmetele. Kuid seda on võimalik kohandada ka arhiivitööks. 20. sajandi lõpu uurijad on eritlenud omaette žanriteks nii arhiivis sõnastatud küsitluskavad kui ka nende küsitluste vastused - kirjutades loodud tekstid, mida on nimetatud Satu Apo pakutud terminiga teemakirjutuseks (Pöysä 2009: 46-49, 53; Jaago 2010: 161162; Savolainen 2016). Ühtlasi on arhiivide korraldatud kogumisvõistlustega seoses Jyrki Pöysä osutanud nende kaastööde (ehk teemakirjutuste) žanrilisele heterogeensusele (Pöysä 2009: 46). Pärimusliku ajaloo (või ka elulugude ja mälestuste folkloristlikus) uurimises on žanr suhteliselt paindlik mõiste: arhiivi kirjalikke kaastöid saab vaadelda kui ühtset žanrit ja ka kui paljude žanrite põimu (Jaago 2008: 99-104). Suulise ajaloo uurimistraditsioonist lähtuvalt viitega Alessandro Poretelli töödele mainib Pöysä, et suulise ajaloo intervjuud (vm sellekohast materjali) võib pidada nii “omaette žanriks" kui "diskursuse 
liigiks, mis põhineb intervjueeritavate ja uurijate omavahelisel kommunikatsioonil” (Pöysä 2009: 46). Ühtlasi võib näha, kuidas žanri ja kommunikatiivsuse teemad diskursuse mõiste kaudu omavahel põimuvad.

Eelkirjeldatust lähtubki folkloristide märkimisväärne huvi pärimusteksti loomis- ja kasutusolukorra vastu, kui küsimuseks on pärimusteksti analüüs. Ja kuigi kõikidel rahvaluule üleskirjutamise perioodidel ei ole huvi esituse vastu olnud samalaadne, nagu seda eeldatakse tänapäeva folkloristlikus uurimises, on neid ülalkirjeldatud põhimõtteid võimalik kohandada erinevat laadi teavet sisaldavate arhiivitekstide uurimiseks. Näiteks Eesti Rahvaluule Arhiivi varem (19. sajandil ja 20. sajandi esimesel poolel) talletatud materjalihulka ning selle liigitus- ja korrastussüsteemi arvestades ei ole ilmselt otstarbekas ega ka võimalik uurimises esiplaanile seada žanri ja rahvaluuleprotsessi dünaamilisi aspekte - tegemist on ju kirjalikult fikseeritud pärimuslugudega. Arhiivis on tekstide kirjapanekud, mis sageli on esile kutsutud kogumissituatsioonis (nagu seda on õieti ka eelmainitud suulise ajaloo intervjuu). Nii ei pruugi arhiivitekstid sisaldada andmeid esitusolukordade kohta ja need ei ava kirjapandud loo seoseid omaaegse tervikliku pärimustekstide maailmaga. Ent see ei takista uurijal arhiivitekstide kontekstualiseerimise kaudu luua uusi seoseid kirjapandu ja üldise pärimusmaailma vahel ning neid mõtestada. Näiteks Aino Laagus pakkus 1970. aastatel strukturalistliku meetodi metshaldjamuistendite analüüsiks, et uurida rahvausundit või metshaldjateadmust (Laagus 2009). 1990.-2000. aastatel on Aado Lintrop tõlgendanud eesti regilaulude motiive ja teemasid (näiteks saani- ja saunategemised, väljend "suude sulg" jms), asetades need soome-ugri rahvausundi konteksti (Lintrop 2016). Rahvaluule analüüsis on seega ühendatud teoreetilised tõdemused, senine teaduspraktika ja konkreetsed uurimisvõimalused. See seos omakorda inspireerib neid küsimusi vaatlema rahvaluule uurimisajaloo seisukohast.

\section{Suulisus ja kirjalikkus rahvaluule uurimises - ajalooline vaade}

Rahvaluule suulisuse nõude üheks märkimisväärseks eelduseks on kujutelm pärimuse ehtsusest: see pidi olema tõepoolest suulisel teel levinud, mitte kirjasõnast (trükistest) pärit. Siin on kaks ajaloolist lähtepunkti. Esmalt see, et valgustus- ja romantismiajal esindas rahvaluule kirjaoskamatu rahva vaimuvara, mida eliidi esindajad kirja panid. Teiseks eelnevast tõukuv arusaam rahvaluule autentsusest, mille järgi rahvaluule on vana, väärtuslik, suuline, variantide rohke, kusjuures suulisust võeti rahvaluule eheduse markerina, kuna selle kaudu sai eristada rahvaluulet kirjakultuuri vormidest (Valk 2005b: 
35-36). Kui vaadelda rahvaluule eheduse ja sellega seotud suulisuse nõuet lähemalt, ilmneb selle eelduse paljutahulisus. Esile tulevad nii ajaloolised aspektid (näiteks teatud ajahetke teaduses valitsevad peavoolud ja kõrvalsuunad ning sellest lähtuvad uurijate valikud) kui ka rahvaluule liikide erijooned.

Eesti folkloristika ajaloo põgusalgi vaatlusel ilmneb, kuidas samaaegselt võivad koos toimida erinevad arusaamad (näiteks kui käsitletakse vastavalt kas salmialbumeid, kettkirju vms kirjalikke pärimusvorme või suulise kultuuri nähtust regilaulu). Samas võib näha, kuidas uurijate seisukohad aja jooksul muutuvad (näiteks muinasjutu uurimises, kus suuliste esituste kirjapanekuaeg langes kokku muinasjututrükiste levikuajaga). Setu rahvajuttude uurimisest ja eriti setude kultuurikirjeldustest toob Kärri Toomeos-Orglaan esile varasemate uurijate rõhutuse setu pärimusmaterjali ehedusest, mille tagas muinasjutuvestjate väidetav kirjaoskamatus: "Seto materjali osas valitseb seisukoht, et kuna XX sajandi alguskümnenditel oli suurem osa rahvast kirjaoskamatu, siis võib nendelt üleskirjutatud juttude puhul eeldada, et need on valdavalt kirjakultuuri mõjudest puutumata. Tekstid, mis aga toetuvad mõnele trükiallikale, on ebaautentsed ega vääri uurimist" (Toomeos-Orglaan 2015: 603). Kirjaoskamatuse (või kirjast puutumatuse) osatähtsus rahvaluule määratlemisel on seisukoht, mis on jäänud esindama teatud uurimissuunda, eriti valdkonnas, mis puudutab kirjandusteaduslikke ülevaateid. Näiteks Cornelius Hasselblatt kirjutab eesti kirjanduse ülevaate rahvaluulepeatükis: "Seesuguse üldise mahajäämuse tulemusena on Setumaal suuline kultuur paremini säilinud ja kirjakultuur domineerib vähem kui mujal Eestis. Ning seetõttu oli Setumaa sõdadevahelisel perioodil ka ainule piirkond Eestis, kus veel ehtsat rahvaluule leida võis" (Hasselblatt 2016 [2006]: 69). Folklorist Kärri Toomeos-Orglaan näitab, et vaadeldaval perioodil, 20. sajandi alguskümnenditel, oli kirjaoskus setu jutustajate igapäevase elu osaks, mistõttu varase folkloristika autentsuse nõue õigupoolest Setumaalt kirja pandud lugudele ei laiene. Küll aga saab vaadelda jutustamise ja kirjasõnast loetu omavahelisi mõjuseoseid.

Folkloristi ees seisvaid analoogilisi küsimusi, kahtlusi ja vastasseise vaeb muinasjuttudega ühenduses ka Ell Vahtramäe. Temagi käsitlusest tuleb esile, et pärimuses ringlevaid muinasjutte ei saa vaadelda lahus trükiste kaudu vahendatud lugudest, iseasi, kuidas selles olukorras hinnata muinasjuttude autentsust või rahvaehtsust (Vahtramäe 2003). Trükitud muinasjuturaamatute leviku tõttu 19. sajandi lõpul ei saa lugude jutustamist selgepiiriliselt eristada sellest, kui nende jutustamine baseerus loetud tekstidel. Kontekstikeskse uurija jaoks aktualiseerub siin rahvaluule eheduse või autentsuse määramise asemel küsimus, kuidas loetud tekste jutustamisel kujundatakse või edasi arendatakse.

Suulise ja kirjaliku piirialal olevatest muinasjuttudest veelgi keerulisem on kõnelda kirjalikest rahvaluulevormidest, näiteks kettkirjadest (Anderson 
1937; Kõiva 1993; Hoppál 2004; Seljamaa 2005: 142-145). Mare Kõiva kõneleb sellega ühenduses kirjalikust pärimusest kui "vanade kultuuride pärusosast" (Kõiva 1993: 12). 1990. aastate folkloristlikes sõnavõttudes ei pruugi selline väide olla küll tavaline, ent on siiski ootuspärane. Et aga Walter Anderson 1930. aastatesse jäävas kettkirjade uurimuses rahvaluule kirjalikkuse üle ei arutle, paneb 21. sajandi uurija Elo-Hanna Seljamaa järeldama, et suulisuse nõue ei saanud Teise maailmasõja eelse perioodi folkloristikas olla sama esileküündiv, kui sellega ollakse harjutud sõjajärgsel perioodil (Seljamaa 2005: 147). Selle tähelepaneku juurde on põhjust allpool veel tagasi tulla. Teine kirjaliku rahvaluule liik on salmialbumid, mida Eestis on uurinud peamiselt Eda Kalmre. Kuid õieti levis suur osa lõppriimilistest lauludestki nii suulises kui ka käsikirjalises vahenduses (vt nt Tedre 2003: 243; Kalmre 2017: 199). Ilmneb, et suulisus rahvaluule tunnusena ei ole alati ja kõikide folkloristide seas samavõrra määrav kui rahvaluule olemuslikele tunnustele üles ehitatud definitsioon seda eeldaks.

Erinevalt rahvaluule kirjalikest žanritest on regilaul selline valdkond, kus suhtumine pärimuse suulisusse tuleb ilmselgelt esile. Alljärgnevas on näide 19. sajandi lõpu tööpraktikast, kus suulisuse nõue kehtis nii rahvalaulude kogumisel kui tekstide esitamisel. Näide pärineb 1889. aasta Oskar Kallase ja Mihkel Ostrovi välitöö-materjalidest. Üks laulikutest, kelle laule toona üles kirjutati, oli Ann Külm Lihulast (H II 2, 383 (503) - 413 (542); vt Ann Külma laulude analüüsi Jaago 2015). Neljakümne üleskirjutuse hulgas on kuus lüroeepilist laulu, neist üks on "Salme neiu", tuntud ka nime all "Tähemõrsja". Selle üleskirjutuse juurde on koguja märkinud, et laulik on õppinud selle laulu kelleltki teiselt, kes omakorda oli leidnud selle trükisest, kusjuures raamatus oli "pool külge Eesti, teine pool Lätti või Ladina keeli" (H II 2, 383 (503)). Kommentaaris on ka üleskirjutaja kahtlus: kas tegemist võiks olla A. H. Neusi koostatud kogumikuga.

Neusi koostatud antoloogias Ehstnische Volkslieder (1850-1852) on esitatud tekstid nii eesti kui saksa keeles. Võimalik, et lauliku viide võõrkeelsele tekstile lähtus sellest? Tõsi, Neusi antoloogias on avaldatud ka üks varem ilmunud "Salme neiu" variant - see pärineb Rosenplänteri Beiträge XI köitest (Rosenplänter 1818: 138-141). Kuid Beiträges on tekst ainult eesti keeles, mistõttu ehk ei olnud Beiträge lauliku kirjeldatud trükis. Kokku on Neusi kogu I osas avaldatud neli "Tähemõrsja" varianti (Neus 1850: 9-23). Ann Külma lauldu ei kattu aga täielikult ühegagi neist. Kui näiteks Neusi antoloogias avaldatud lauludes jutustatakse "noorest naisest" või "eidest", kes "läks karja saatemaie", siis Ann Külma laulu peategelaseks on "mina" ("Läksin karja saatemaie"). Sellegi poolest on Ann Külma esitatu sõnastuselt kõige lähem Neusi antoloogias avaldatud A-variandile. See on eelmainitud Beiträges avaldatud A. F. J. Knüpfferi Virumaalt kirja pandud tekst (Neus 1850: 448). 


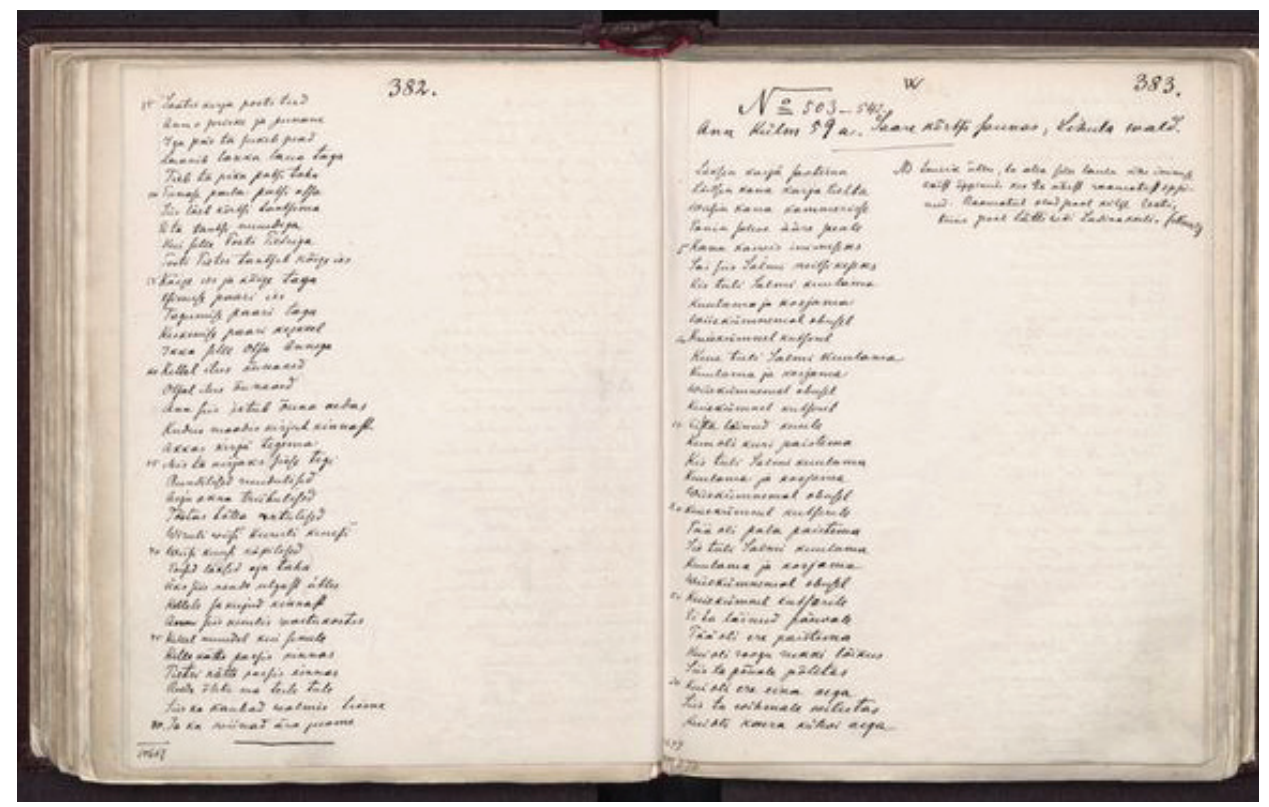

Laulukogujate kommentaar Ann Külmalt üles kirjutatud laulu juurde: "Laulik ütles, ta olla selle laulu ühe inimese käest õppinud, kes ta ühest raamatust õppinud. Raamatul olnud pool külge Eesti, teine pool Lätti või Ladina keeli. (Neuss?)”. Eesti Rahvaluule Arhiiv, H II 2, 383 (503).

Samas on aga tähelepanuväärne, et Ann Külma "Tähemõrsja” (paralleelnimega "Salme neiu") varianti "Eesti rahvalauludes" (1932) ei avaldata. Tegemist on lüroeepiliste laulude kogumikuga, kus on esitatud sama tüübi kõik arhiivis olemasolevad variandid. "Salme neiu" lauluüleskirjutusi on selles kogumikus 323, neist üheksa on Lõuna-Läänemaalt, millest kuus pärinevad Kallase ja Ostrovi eelkirjeldatud kogumisretke aruandest 1889. aastast, üks on aasta hiljem Mihkel Ostrovi kirja pandud variant, kaks varianti on Hurdale saatnud kaks kohalikku kogujat vastavalt 1888. ja 1890. aastal. Et Ann Külma lauldud varianti kogumikus avaldatute hulgas ei ole, siis järelikult ei peetud seda rahvaehtsaks: oli ju Ann Külm selle õppinud kelleltki teiselt, kes omakorda oli laulu leidnud raamatust.

Kui nüüd tagasi tulla rahvaluule kirjalike vormide juures Walter Andersoni tööga seoses mainitud tõdemuse juurde, et tõenäoliselt ei olnud 1930. aastatel suulisus rahvaluule määratlemisel sama oluline kui hilisemal perioodil, siis vanema rahvalauluga seonduvalt seda väita ei saa. Oli ju Walter Anderson ka selle regilaulude teadusliku allikapublikatsiooni koostajate hulgas. Pigem 
kinnistub veendumus, et suulisuse märkamine ja arvestamine võib samaaegselt olla erineva kaaluga, sõltudes käsitletavast žanrist.

On selge, et vanema rahvalaulu kriteeriumiks 19. sajandi lõpu ja 20. sajandi alguskümnendite folkloristikas oli laulude suuline algupära ja levik. Kuid mida õieti öelda laulikute kirjaoskuse kohta? Kuigi lauludes selgitatakse, et laulud on õpitud töötegemise kõrvalt, mis tõenäoliselt nii oligi, siis 19. sajandi teisel poolel ei olnud laulikud kirjaoskamatud. Näiteks Ann Külma (1830-1898) kohta on personaalraamatus märgitud, et ta "loeb puhtalt" (liest rein: EAA.1244.1.156: 18). ${ }^{4}$ On ootuspärane, et laulikute lugemisharjumused seostusid kirikukirjandusega, ent akadeemilisele publikule mõeldud Neusi lauluantoloogia ei ole kindlasti tolleaegsete külaelanike tavakirjandus. Neus töötas Läänemaal ja kogus sealt rahvaluulet ning lasi seda teha ka oma õpilastel (Laugaste 1970: 96-101, 114-115). Võib-olla mõned tema omaaegsed õpilased olid selle raamatuga tuttavad? Ka on võimalik, et see raamat sattus 1842. aastal asutatud Karuse kiriku koguduse raamatukokku. ${ }^{5}$ Nimelt oli Karuse pastor Friedrich Wilhelm Anton Hasselblatt koos Neusiga Eestimaa Kirjanduse Ühingu liige (Schröder 2003: 65). Nii muinasjuttude kui ka regilaulude uurimisloost ilmneb, et isegi siis, kui teadlased lähtusid rahvaluule suulisuse nõudest, eksisteerisid need tekstid siiski kirjakultuuri ajajärgul. Laulude puhul, kõnelemata muinasjuttudest, ei saa eeldada, et nende lauljad või jutustajad ei tundnud ega kasutanud kirjasõna. Tegelikus elus ei olnud suulisust ja kirjalikkust päriselt võimalik lahutada. Küll aga on sellegi põgusa vaatluse puhul aimatav, mil viisil pakuvad kultuuri suulised ja kirjalikud vormid lauljatele ja jutustajatele, nagu ka kuulajatele ja lugejatele mitmetasandilisi võimalusi, mis kohati põimuvad ja kohati lahknevad.

Rahvaluule kirjalikud vormid (sh käsikirjadena levivad lõppriimilised rahvalaulud) on pakkunud 20. sajandi uurijatele küll huvi, ent need uurimisvaldkonnad ei ole olnud folkloristika peateel ega ole jätnud ka olulist jälge rahvaluule definitsioonidesse. Pigem ilmneb käsitlusest, et kirjalikult levinud tekstide puhul on suulisus nende tekstide rahvaluuleks määratlemise peamine tegur. Näiteks uuema rahvalaulu uurimustes kasutab Ülo Tedre ka käsikirjalistes laulikutes levinud tekste (Tedre 2003). Rahvaluuleteooria ülevaates aga rõhutab ta, et kuna need tekstid levisid ka suuliselt edasiantuna, siis just see - suuline levik - "annab aluse vaadelda neid rahvaluulena” (Tedre 1998: 562). Eelöeldu sobitub kultuuriuurimise sellise raamiga, kus rahvaluulele seati ajalised piirid. Näiteks Euroopas seostati rahvaluule modernismieelse talupojakultuuriga (vrd Anttonen 2005: 27 jj). Kirjaoskuse omandamist aga seostati ühiskonna moderniseerumisega (vrd Liljewall 2013: 36). Selle seisukoha järgi oli rahvaluule modernses ühiskonnas olemas vaid arhiivis või töötlustes, sest oma loomulikus esituskontekstis võis rahvaluulet kohata modernismieelses 
külakogukonnas, kus kirjakultuuril ei olnud olulist rolli (v.a ehk kirikukirjandus). Sellest ideest lähtus ka näiteks Monumenta Estoniae käsitlus Oskar Kallase sõnavõtus, mis on avaldatud "Eesti rahvalaulude" I osas. Kallas jaotab rahvaluule ehk "muinasluule" kolme ajajärku: Estonia antiquae, mil "luule on maarahva elu oluline osa", Monumenta Estonaie antiquae, mil "luule annab tõusvale Eesti rahvale sisu, tuge" ja Fundamenta Estonae novae - "luules näeme tulevase arenemise sugemeid" (Kallas 1926: V). Samas tasub ikka ja jälle rõhutada, et folkloristika peatee ja teoreetiliste sedastuste kõrval on alati ka paralleelarenguid, mis muudavad tegeliku uurimispildi tunduvalt kirjumaks. Olgu siinkohal taas esile toodud Walter Andersoni töö mitmeplaanilisus.

\section{Suuline kirjandus}

Kui toimusid muutused kultuuriuurimises üldiselt ja rahvaluulet hakati mõistma pidevalt jätkuva-uueneva protsessina, siis kerkis esile ka küsimus kirja pandud rahvaluule suulisusest. Ent sellele küsimusele eelnes rahvaluule käsitlemine suulise ehk kirjutamata kirjandusena. Seda eriti keeleruumides, kus kirjandus, kooliharudus jms kirjakultuuri ilmingud ei olnud 19. sajandil kesksel kohal (vt nt Beyer 2003: 82). Nii oli see ka Eestis ja Soomes (Apo 1994: 22-23; Bronner 2017: 9). 19. sajandil oli eestikeelse sõnaloomingu märkimisväärne osa seotud rahvaluulega, mistõttu selleaegsed arutelud rahvaluule üle olid läbi põimunud kirjandusaruteludega ja vastupidi (Roll 1992). On siiani tavaline, et rahvaluulepeatükk kuulub nii kooli kirjandusprogrammidesse kui ka eesti kirjandusajaloo ülevaateteostesse (vt nt Järv 2001; Hasselblatt 2016: 34-37, 49-94).

Millist osa pärimusest kirjeldatakse suulise kirjandusena? Eesti kirjandusloo üks esimestest ülevaadetest, 1899. aastal ilmunud Tõnu Sanderi "Eesti kirjanduse ajaloo" I osa on pühendatud rahvaluulele. ${ }^{6}$ Ülevaate autor määratleb kirjanduse ja rahvaluule ühisosana arusaama "rahva vaimuvarast": "Kirjanduse ajalugu harutab siis, lühidalt öeldes, rahva vaimuelu edenemist sellel mõõdul, nagu see tema suusõnalistes ja kirjalistes vaimutöödes nähtavale tuleb" (Sander 1899: 6-7). Sada aastat hiljem kirjeldab Ülo Tedre seda nii: rahva vaimne pärimuslik looming "oli n-ö kirjutamata kirjandus, mis enne kirjaoskuse üldistumist täitis olulisel määral kirjasõna otstarvet” (Tedre 1998: 545). Rahvaluuleliikidest (põimunult "Kalevipojaga"7) käsitleb Sander regilaule, rahvajutte ja lühivorme. Samu rahvaluule alaliike (laulud, jutud, lühivormid) käsitleb ka Tedre. Ent Tedre jätab välja "Kalevipoja”, kuid käsitleb rahvalaulude alalõigus ka käsikirjalisi laulualbumeid, illegaalset värsskirjandust ning nn laulukirjandust - trükitud populaarseid laulukogumikke. Ent nagu eelpool 
mainitud, põhjendab ta nende käsitlemist rahvaluulena sellega, et neid tekste vahendati ka suuliselt. Nagu eelmainitud autorid, kirjeldab ka Ants Järv rahvaluuleliikidest rahvalaule, -jutte ja lühivorme. Sarnaselt Tedrele mainib ta käsikirjaliste ja trükitud laulikute mõju uuemate rahvalaulude levikule (Järv 2001: 20). Samas kirjaliku rahvaluule teema jutuks ei tule. Sarnaselt Sanderile mõtestab ta rahvaluule ja kirjanduse seose nende vaimse ühisosa kaudu. Järv toob esile rahvaluule "kindlailmelise poeetika" ja aegade vältel väljakujunenud temaatika, mis teeb rahvaluulest "eestlaste kultuuriloo olulise koostisosa" (Järv 2001: 18). Järv kirjeldabki rahvaluulet pigem Eesti ajaloo kui sõnakunsti raamistikus. Seos kirjandusega tuleb enam esile rahvaluule teemade ja motiivide kasutamises autoriloomingus. Võib väita, et Järve käsitluses ei ole rahvaluule ja kirjanduse seosed esil mitte niivõrd loomingu- (suuline versus kirjalik), kuivõrd kultuuriajaloo aspektist. Cornelius Hasselblatt käsitleb "Eesti kirjanduse ajaloo" rahvaluule peatükis seda osa pärimuskultuurist, mida saab vaadelda sõnas väljendatava vaimuloominguna (Hasselblatt 2016: 49 , 51). Sel põhjusel hõlmab temagi oma vaatlusse vaid rahvalaulud, -jutud ja lühivormid, kus suulisus on rahvaluule üks viiest põhitunnusest (samas: 51). Rahvaluule kirjalikest vormidest juttu ei tule, v.a anekdootide juures (samas: 66-67). Tähelepanuväärne on Hasselblatti rõhutus, et eesti kirjandus ei kujunenud rahvaluule pinnalt. Lineaarse seose asemel näitab ta, et suuline ja kirjalik kultuur kujunesid paralleelselt, põimudes 19. sajandil (samas: 50). See sobitub muuhulgas ka väitega laulikute ja jutustajate kirjaoskusest ehk suulise ja kirjaliku kultuuri paralleelsusest, millest oli juttu eelpool. Suulise kirjanduse käsitlustele oli kõigil vaadeldud juhtudel iseloomulik, et rahvaluule ja kirjanduse ühisosaks on rahvaluule mõtestamine vaimse sõnaloominguna, mis omakorda piirab rahvaluule valdkonda kolme suurema alaliigiga - rahvalaulude ja -juttude ning lühivormidega.

Folkloristid on suulise kirjanduse vaatepunkti nii toetanud kui ka eitanud. Viimasel juhul on rõhutatud kirjanduse ja rahvaluule vaheliste piiride selgust, viidates rahvaluule kollektiivsusele ja stereotüüpsele vormelikeelele (Apo 1994: 22; vrd Laugaste 1986: 52). See, kas käsitleda rahvaluulet kirjanduse osana (suulise kirjandusena) või vastupidi, näidata kirjanduse ja rahvaluule erinevust, lähtub mõlemal juhul arusaamast, et rahvaluule on sõnalooming. Kuid miks üks ja seesama tunnus pakub võimaluse vastupidisteks seisukohtadeks? Kui Ruth Finnegan käsitleb nii suulisi kui ka kirjalikke vorme kirjandusena (Finnegan 2012 [1970]: 3-14), siis Jack Goody nõustub Finnegani väitega vaid osaliselt tegemist on loominguga. Goody aga ei keskendu loomingu mõtestamisel ainult lõpptulemusele, vaid ka protsessile ja ta näitab, et loomeprotsessi poolest erinevad suuline ja kirjalik teineteisest märkimisväärselt. Suulises kultuuris on lugude edasikandumise ainsaks viisiks nende esitamine, kus avaldub ka indi- 
viduaalne loovus, kuid jätkuvate esituste käigus "individuaalne käekiri alati kuhtub" (Goody 2005 [1977]: 45-47). Sellest lähtuvalt ei sobi suuliste lugude analüüsiks kirjanduse analüüsimise võtted, sest lugude esituste käigus loodavaid variante ei ole võimalik käsitleda nagu "autori teose lõplikku käsikirjahulka" (samas: 49). Eesti näitel on selles kontekstis kõnekas suur arhiivitekstide hulk, mis ahvatleb neid käsitlema piiritletud ja lõpliku käsikirjahulgana. Ometi on needki suuliste esituste variandid, mis on üles kirjutatud loomeprotsessi ühes ja piiritletud situatsioonis. ${ }^{8}$ Arhiivis olevate variantide rohkus omakorda pakub folkloristidele pinna, mis eristub kirjandusteaduslikust tekstianalüüsist: rahvaluuleteaduses esindavad variandid pärimusprotsessi võrdväärseid osi, mis ei asetu üksteise suhtes näiteks originaali ja koopia või mustandi-eeltöö ja lõpptulemuse seostesse.

Võib järeldada, et suulise kirjanduse kontseptsioon sobib rahvaluule käsitlemiseks siis, kui vaadeldakse rahvaluule kirjapanekuid - see toob kaasa rahvaluule edasikandumise tavalise tee (varieeruv esitus) katkemise. Seega esindab "suuline kirjandus" rahvaluule käsitlemist kirjakultuuri ja kirjanduse vaatepunktist, mis toob esile rahvaluule teatud omadused, näiteks et tegemist on väljakujunenud kujundkeelega. Ühtlasi kaasneb selle lähenemisviisiga ka osutamine rahvaluule motiivide ja teemade kasutamisele kirjanduses, ilmnegu see siis kas "Kalevipoja” kriitikana Sanderi töös või lihtsalt viitena Järve käsitluses: "Eesti kirjanike hulgas on arvukalt neid, kes on arvestanud või otseselt kasutanud oma loomingus meie rahvaluule rikkalikke allikaid" (Järv 2001: 22).

\section{Rahvaluule kirjanduses - küsimus rahvaluule suulisusest}

Ajalooliselt on viimati mainitud seos - rahvaluule, millest on võetud ideid ja ainest kirjandusse - väga oluline, sest see on oluliselt kujundanud ka arusaama rahvaluulest kui suulisest või kirjutamata kirjandusest. Ometi ei ole arusaam kirjanduse ja rahvaluule seostest ühetaoline. Pigem on tegemist ajas muutuvate kultuurispetsiifiliste hoiakutega (Lawson 2010). Euroopa, sealhulgas Eesti folkloristikas on rahvaluulehuvi märkimisväärseks alguseks peetud James Macphersoni "Ossiani laule” (1760-1765). Väidetavalt põhines see rahvaluulel ning osutus oma ajastu kirjandusturul menukaks (Mulholland 2009). Ka Herderi rahvalaulude kogus ei eristu selgepiiriliselt autorilooming rahvaluulest, pigem on tegemist tänapäeva mõistes töötlustega (Paškevica 2016: 59). Samas kujundas Herderi tegevus oluliselt nii tolleaegsete kui hilisemate intellektuaalide rahvaluuleteadmust. Analoogiline on olukord ka Faehlmanni müütiliste muistenditega - nii vajadus nende järele kui ka populaarsus lähtus tolleaegse 
kirjanduse eelistustest ja mudelitest. Kõik need rahvaluulega seotud kirjandusteosed kujundasid ühelt poolt avalikkuse rahvaluulehuvi, kuid käivitasid paralleelselt ka kriitilise arutelu (vt nt Sander 1899: 29-30). Millised ka ei olnud 19. sajandi autorite kavatsused oma kirjatöödes esitada suulist pärimust, põrkusid nad igal juhul kokku kirjandusliku maitse eelistuste ja traditsioonidega. Suulise teksti ülekanded kirjalikku vormi või ka rahvaluulest tõukunud töötlused (mugandused) tõid kaasa mitmeid tekstimuutusi. Niina Hämäläinen uuris selles kontekstis Elias Lönnroti koostatud kogumikku "Kanteletar" (1840), kus on kasutatud lüürilisi rahvalaule. Ta näitab, et külainimeste mõttemaailm oli selleaegsele raamatulugejale võõras, mistõttu suuline rahvalüürika tuli sõnastada lugejale arusaadavaks (Hämäläinen 2017: 173-174). Samalaadseid näiteid võib leida Kreutzwaldi kirjadest Schultz-Bertramile: ikka ja jälle kohtab neis arutelusid, millest nähtub kultuuritõlke keerulisus. Ühelt poolt on Kreutzwald hädas kriitikutega, kes nõuavad temalt rahvaehtsat eepost. Samas aga läheb rahvaluulest pärit väljenduslaad vastuollu nii seltskondlike tavade kui ka kirjandusliku maitsega. Kreutzwald ei saa kujutada näiteks regilauludest tuttavaid väljal peetavate pidude kirjeldusi, sest see ei ole kultuuriliselt arusaadav neile, kes seda teksti loevad, kuna viimased käivad ballil, mida omakorda jällegi selleaegse suulise kultuuri viljelejad ei tundnud. (Vt Kreutzwald 1959: 38-41.) Teise maailmasõja järgses eesti folkloristikas tõusis rahvaluule ja kirjanduse seos nii institutsionaalselt kui ka uurimisparadigmast lähtuvatel põhjustel taas omal moel esile. Selleaegses teaduslikus käsitlustes seotakse folkloristika sünd rahvaluule tunnustamisega poeetilise loominguna. Näiteks rõhutab Vaina Mälk, et just Herder oli see, "kes 18. sajandi 70-ndatel aastatel tõstis tollal veel küllalt mõjusale klassitsistlikule, rahvapõlglikule kunstikäsitlusele vastukaaluks teravalt ja julgelt üles mõtte luule rahvalikust olemusest ja päritolust” (Mälk 1963: 17). Võib-olla on see akadeemiline raam üheks põhjuseks, miks eesti rahvaluuleteoreetiline keskustelu kinnistus pikaks ajaks (vähemalt 1980. aastateni) kirjandusteadusliku vaate külge, andmata ruumi teadusala tegeliku praktika lõimimisele teoreetilisse käsitlusse. Rahvusvaheliselt aga ilmnes, et mida enam uuriti rahvaluulet kirjanduse kaudu, seda enam kerkis ka esile küsimus, mille poolest kirjandus ja rahvaluule erinevad. Selle protsessi esiletulevamaid jooni võib näha suulisuse uuringutes: mida õieti tähendab see, et rahvaluule on suuline?

Suulisuse uuringud seostuvad näiteks 1970.-1980. aastatel esile kerkinud etnopoeetikaga, mille raames huvituti sellest, kuidas toimib poeetiline korrastatus suulises esituses, sealhulgas see, mida ei saa kirja panna, nagu pausid vm häälega seotud emotsioonid (Quick 1999; Webster \& Kroskrity 2013). Samuti seostuvad suulisuse uuringutega meelespidamise või mäluga seotud küsimused. Folkloristikat on selles vallas oluliselt mõjutanud kreeka ja ladina keele 
ning kultuuri uurija Milman Parry ja tema mõttejärglase Albert B. Lordi töö (Foley 1988: 41). Pühendudes 1930. aastatel "Iliase" ja "Odüsseia" uurimisele, suundus Milman Parry koos Albert B. Lordiga välitöödele tolleaegsesse Jugoslaavia kuningriiki Balkani poolsaarel. Välitöö eesmärgiks oli helisalvestada juba kirjas dokumenteeritud laule, et uurida, kuidas neid suulises esituses taasluuakse. Parry suri 1935. aastal, ent Albert B. Lord jätkas nii välitöid kui ka uurimust. Sellest tööst lähtub folkloristika klassikasse kuuluv raamat "The Singer of Tales" (1960), mis rajanes Lordi 1949. aastal Harvardi ülikooli võrdleva kirjanduse osakonnas kaitstud doktoriväitekirjal (Elmer 2013). Just need suulisuse uuringud (nt vormeliteooria) on aluseks folkloristide väidetele, kus tuuakse esile suulise rahvaluule loomisviiside erinevus kirjaliku teksti loomest. Ja ühtlasi põhjendatakse, miks ei sobi kirjanduse kujundkeele analüüsivõtted suulise rahvaluule uurimiseks. Jättes hetkel kõrvale vormeliteooria kaudu selgitatu ja selle võrdluse rööbiti toimunud suulise pärimusluule uurimisega - näiteks Eesti kontekstis on neid teemasid käsitlenud Liina Saarlo oma väitekirjas (Saarlo 2005) -, on oluline esile tuua, et suulisuse uuringud eeldavad teadusalade vahelist koostööd. Näiteks suulisuse teooria kujunemise ajaloo ülevaates rõhutab John Miles Foley selle teooria lähtumist filoloogiast, millele lisandusid folkloristlikud välitööd ${ }^{9}$ (Foley1988: 33). Vormeliteooriaga paralleelselt on jätkuvalt arutletud suulise pärimuse ja selle kirjapanekute omavaheliste seoste üle. Ilmneb, et mitte kõikide tekstide puhul ei saa kasutada välitööandmeid, samuti tuuakse esile loomeviiside (improviseerimine versus pähe õppimine) traditsiooniregioonide erinevusi Euroopas, nagu ka suulise kultuuri pärimustekstide pikkuse teema: näiteks on ilmnenud, et väide suulise kultuuri tekstide lühidusest ei pea paika jms (vt Mundal \& Wellendorf 2008). Igal juhul on suulisuse uuringutes keskne see, et tegemist on mitmeid teadusalasid lõimiva aruteluga (erinevalt suulise kirjanduse käsitlusest, kus rahvaluulet vaadeldakse kirjanduse kaudu).

\section{Suuline ajalugu}

Suulise kirjanduse kontseptsioon ärgitab omakorda küsima, kuidas selle taustal avaldub ajalooteadusest välja kasvanud uurimissuund suuline ajalugu. Kuigi suuline ajalugu ei ole uurimissuunana Eestis kuigi aktuaalne, on ka siin rahvaluule üks funktsioone olnud vahendada teavet rahvapärase minevikutõlgenduse kohta. Seda alustades Kreutzwaldi ja Hurda aegadest, läbides Eesti Kirjanduse Seltsi ajalootoimkonna ja Akadeemilise Ajaloo Seltsi tegevuse, lõpetades 1990. aastatel kujunema hakanud pärimusliku ajaloo uurimissuunaga. 
Suulise ajaloo nimetuse ja uurimisviisi institutsionaalne algus on seostatav 1948. aastal Columbia ülikoolis Allan Nevise algatatud projektiga (Grele 1996: 64; Thomson 2007: 22). Ameerikast lähtuva suulise ajaloo kui ühe uurimisviisi enesemääratlus seostub intervjuudega ning vajadus sellise uurimisviisi järele lähtus tavaliste ajalooallikate puudumisest kas teatud ajalooperioodide või sündmuste uurimises või ka ühiskonna arengust tingitud olukorras, kus dokumenditüübid muutusid (Grele 2007: 12). Euroopa analoogiline uurimistraditsioon on mõnevõrra teine (vrd nt Poola teadusruumis Kurkowska-Budzan 2014; Soomes Pöysä 2009). Kuigi mälestused ja rahvaluule on ajaloo uurimise eesmärgil kõneks olnud samavõrra kui suuline kirjanduski, ei ole suulise ajaloo mõiste Eestis märkimisväärselt rakendunud. (Õieti on see mõiste (oral history) tänapäevane katustermin, mis ühendab mitmete regioonide rahvapärase ajaloo uurimise traditsioone.) Pigem seostub eesti suulise ajaloo uurimise traditsioon mälestuste või ajaloolise traditsiooni mõistega.

Rahvaluule ja ajaloo omavaheliste seoste teema oli aktuaalne nii 19. sajandil (rahvaluule pakub vaate ajaloole rahva endi silme läbi) kui ka hiljem (kui folkloristid tegelesid ajaloosündmustest laulmise või jutustamise uurimisega). Kreutzwald kirjutab ennemuistsetest juttudest, "mis otse kui peeglist vana põlve rahva kueu üles näitab" (Kreutzwald 1861: 26). Jakob Hurt kasutas mõistet "rahvamälestused": "Kõige vanemate ja tähtsamate tunnistuste hulka, mis ühe rahva elust ja ajaloost märku annavad, tulevad vaidlemata selle omad mälestused - rahvamälestused - arvata", ütleb Hurt 1896. aastal muinasaja uurijate kongressil peetud kõnes (Hurt 1989: 75). Tema käsitlustele tuginesid nii kaasaegsed kui ka hilisemad rahvapärasest minevikuteadmusest huvitunud ajaloolased oma tegevuses.

Kuna Hurt kõneles tänapäeva mõistes rahvaluulest, võib küsida, mille poolest erinesid Hurda "rahvamälestused" nendest mälestustest, mille vastu ajaloolased huvi tundsid? Vastus peitub selles, kui kauget aega ühes või teises (vastavalt "rahvamälestustes" või "ajaloolises traditsioonis") kirjeldati. "Rahvamälestuste" sünonüüm oli "vanavara". Seda mõistet kasutab Hurt ka eelmainitud kõnes, rõhutades, et tegemist on nimelt "Eesti muinasaja varaga" Hurda kogutud rahvaluule oli seega eelkristliku (muinasaja) ajaloo uurimise allikaks (Hurt 1989: 76). Samal ajal avaldab Ado Grenzstein ajalehes Olevik üleskutse saata talle mälestusi lähiajaloo-sündmustest - see valdkond toona rahvaluule alla ei kuulunud: "[---] Pühajärve sõjast, Mahtra tülist ja sarnastest juhtumistest, niipalju kui vanad inimesed neist veel mäletavad jutustada" (Grenzstein 1898: 446). 1920.-1930. aastatest pärineb ulatuslik kogu ajaloolise traditsiooni üleskirjutustest (EKLA f 199 ja 200). Rahvaluule ja ajaloosündmustele tuginevad mälestused olid nii 19. sajandil kui ka 20. sajandi esimesel poolel erinevad valdkonnad, ometi on seoseid nende alade vahel alati märgatud 
ja neid omal moel ka tõlgendatud (Jaago 2014). Folkloristliku uurimise objektiks on mälestused siis, kui neid käsitleda mitte niivõrd ajaloosündmuste, kuivõrd ajaloost jutustamise vaatepunktist.

Ent mis tingis ajaloolaste huvi folkloristika vastu? ${ }^{10}$ Selle põhjustas suulise ajaloo uurimisviisi kriitika, milles osutati mälestuste subjektiivsusele (Grele 2007: 12-13; Thomson 2007: 23). Kriitikud jõudsid järeldusele, et mälestused ei ole usaldusväärsed ajaloo uurimise allikad, kuna inimesed lisavad sinna fakte ja emotsioone, mis hämardavad sündmuste tegelikku kulgemist. Ühelt poolt nähtub, kuidas kirjakultuuri muster oli aluseks suulise kultuuri kirjeldamisele: intervjuud kui subjektiivsed allikad ei kohandu uurimiseks analoogiliselt objektiivseteks hinnatud kirjalikult fikseeritud dokumentidega. Ent samas tõstatus ka küsimus suulise kultuuri (või lihtsalt suulise esituse) eripärast: kuidas näha allikate subjektiivsuses mitte viga, vaid võimalust (Thomson 2007: 23; Heimo 2010: 42-44). Need teemad lähendasid suulise ajaloo uurijaid 1970.-1980. aastatel nii narratiivi- kui mälu-uurijatele (Lorenz 2013: 101-102). Suulise ajaloo uurimisviisi raames tõstatas 1970. aastatel suulisuse küsimuse Alessandro Portelli nüüdseks klassikaks saanud artiklis "What makes oral history different" (Portelli 2000). Ta osutas suulise ajaloo allikas - intervjuus - olemasolevatele andmetele, mis kirjas (või kirja panduna) ei avane (emotsioonide, pauside, hääle tooni ja tempo muutused ning nende omavaheline seos intervjuu vältel). See on analoogiline suulise teksti poeetilise korrastatuse küsimusega, mis on esil ka etnopoeetikas. Suulisuse analüüsivõtteid (nagu pakub neid välja Portelli) võib tõsieluteemalistes intervjuudes taas ja taas kohata. Näiteks Gadi Benezer (2014: 34-36) loetleb trauma markereid (trauma signals) eluloolisel jutustamisel, tuues muuhulgas esile pausid, emotsioonide kontrolli kadumise, korduva esituse ja rõhutuse (mis on tõsieluloo suulises esituses tavaline), hääle muutused, aga ka pilgu jms, mis kirjalikus tekstis sellisena ei ilmne.

Eelnevast ekskursist võib näha, kuidas suuliste esituste kirjapanekud lähendavad need kirjakultuurile. See omakorda tõstatab 20. sajandi keskel ja eriti sajandi teisel poolel küsimuse allikate suulisuse eripärast, seda nii suulise kirjanduse kui ka suulise ajaloo kontekstis. Lõpuks on rõhutamisväärne tõik, et suulisuse uuringud on interdistsiplinaarse uurimise alaks.

\section{Kokkuvõte}

Tänapäeva folkloristika vaatepunktist kergitab suulisuse ja kirjalikkuse seos esile mitu küsimust: millega seoses tuuakse rahvaluule omadusena esile suulisus?; kuidas mõjutab suulise esituse kirjapanek seda, mida uuritakse või 
mida uurida saab?; kuidas muutub suuliselt esitatud tekst selle kirjapanemise käigus? Need küsimused on esitatud sellisest teoreetilisest vaatepunktist, kus suulisus ei kuulu rahvaluule olemuslike tunnuste hulka. Pigem on suulisus üks rahvaluule esinemisviise kirjalike jm vormide kõrval.

Suulisuse ja kirjalikkuse vaheline seos on folkloristikas olemas selle teadusharu sünnist alates. Ilmnedes esmalt selleski, et suuliselt ringlev pärimus sai uurijatele kättesaadavaks rahvaluule kirjapanekute kaudu ja folkloristika algusajal oluliselt ka (ilu)kirjanduse vahendusel. Ühtlasi ilmnes, kuidas rahvaluule suulisus selles protsessis ka poeetilise keele mõttes taandus, sest rahvaluule kirjapanemisel, veel enam selle avaldamisel tuli silmas pidada kirjakultuurist lähtuvaid ootusi. Kirjapandu hakkas omakorda kujundama rahvaluule korrastamist ja sellest arusaamist kirjakultuurile omastest arusaamadest lähtudes. Samas, ja ühtlasi vastuoluliselt eelöeldule, rõhutati rahvaluule suulisuse printsiipi, et selle kaudu eristada rahvaluulet kirjandusest. Vastuolu taandub, kui mõista, et suulisuse nõue kehtestati mitte rahvaluule esituse, vaid päritolu, kirjapanemise eelse levikuviisi kohta. Mida enam hakati tegelema esitusega (sh loomisega esituse kaudu), seda enam lisandus küsimusi suulise kultuuri poeetika erijoontest.

Paralleelselt rahvaluule kirjapanemise ja folkloristika kujunemisega toimis rahvaluule seostamine nii kirjanduse kui ajalooga. Sellised kontseptsioonid nagu "suuline kirjandus" ja "suuline ajalugu" ("ajalooline traditsioon") on esil, kui rahvaluules nähakse võimalust kompenseerida kirjanduse või ajaloodokumentide puudumist. Need kontseptsioonid lähtuvad kirjakultuuri eeskujudest. Ent mida enam märgatakse suuliste allikate iseseisvat eripära (ja samal ajal, mida enam taandus folkloristikas rahvaluule piiritlemine valmisoleva tekstina), seda enam hakatakse uurima esituse viise, sh suulisuse eripära, kuna selles nähakse omaette tõlgenduseks vm uurimisviisiks vajalikke kõnekaid andmeid. Suulisuse uuringud omakorda aga eeldavad teadusvaldkondade vahelist koostööd. 


\section{Kommentaarid}

1 Artikkel on seotud Eesti Haridus- ja Teadusministeeriumi rahastatava projektiga “Traditsioon, loovus ja ühiskond: vähemused ja alternatiivsed diskursused”(IUT 2-43).

2 Olgu siinkohal rõhutatud, et suulisus ei olnud uurimispraktikas nii järjekindel nõue kui võiks seda eeldada rahvaluule definitsioonist.

3 Marleen Nõmmela (Metslaid) on taastanud Gustav Ränga 1920. aastatel tehtud välitööde terviklikkuse, kasutades selleks Eesti Rahva Muuseumi eraldiseisvaid kogusid (etnograafilised kirjeldused, välitööpäevikud, esemete ja fotokogu). Ilmneb, et sama välitöö materjalid jaotati muuseumi kogudesse vastavalt selleaegse uurimismaterjali korrastusviisile. "Tavaliselt Ränga välitöödel loodud allikad üksteisele ei viita, erandiks on vaid korjamis- ja inventariraamatud. Ristviitamise puudumine on põhjendatav ERM-i tollase välitööde kontseptsiooniga, mille järgi eri allikates nähti omaette väärtust. Välitööd tervikuna ei olnud muuseumi jaoks olulised” (Nõmmela 2007: 156). Analoogiline süsteem valitses ka rahvaluulearhiivis, kus materjali süstematiseerivates kartoteekides ja koopiamappides liigitati pärimustekstid tekstiliikide järgi (laulud, jutud jne) eeldusel, et see sobitub rahvaluule uurimisega.

4 Samalaadseid rõhutusi - koolihariduse puudumisele vaatamata oskas laulik lugeda, kusjuures tema lugemisvara hulka kuulusid nii vaimulik kirjandus kui ka ajalehed ja juhuslikult kättesaadavad ilmalikud raamatud, võib leida Kuusalu suurlauliku Mai Kravtsovi (1843-1933) elulookirjeldusest (Kokamägi 1957: 45-46).

5 Teave Karuse raamatukogu asutamise aasta kohta pärineb kodu-uurimuslikest töödest (vt nt Schröder 2003: 64).

6 Aasta varem, 1898. aastal ilmunud Karl August Hermanni "Eesti kirjanduse ajaloos" rahvaluule osa ei ole (Hermann 1898). Vt Hermanni ja Sanderi kirjandusülevaadete võrdlust: Hasselblatt 2016: 34-35.

7 Ühelt poolt Tõnu Sander eristab Kreutzwaldi "Kalevipoja” rahvaluulest, viidates eepose kriitikutele: eeposes ei ole piir "rahva "suu järel" truuilt üleskirjutatud" lugude ja Kreutzwaldi omaloomingu vahel selge. Teisalt tunnistab ta "Kalevipoja" siiski "Eesti rahva muistse mälestuste" põhjal valminud teoseks (Sander 1899: 29-30).

8 Lõuna-Euroopa rahvalaule ja esitusi uurinud Albert B. Lord kirjeldab lauluüleskirjutusi nimelt kui üht erilist esitussituatsiooni (a special performance), mis ei ole laulikule sugugi tavaline olukord, ent on mõistetav siiski kui üks konkreetne esitus loo esituste seerias (Lord 1997: 124).

9 Ingliskeelses kirjanduses kasutatakse siin antropoloogia (mitte folkloristlike välitööde) mõistet. See tuleneb teadusajaloolistest ja regionaalsetest erijoontest. Analoogilisi arenguid võib aga leida ka eesti teadusajaloost. Näiteks 1920.-1930. aastatel toimunud arutelu regilaulude skandeerimise teemadel. Kirja pandud laulutekstide uurimisest jõuti küsimuseni, kuidas laulik oma laule esitab: kas pigem skandeerides (s.o nt kolme- või viiesilbiliste sõnade laulmisel enam värsirõhke arvestades: hulkusid unesulased) või järgiti lauldes sõnarõhke (hulkusid unesulased). Ühtlasi kujunesid siis oluliseks allikaks laulu esituse kirjeldused. Selle teema toob arutellu Harald Paukson (1930), kes näitena tsiteerib Loode-Eestis laule kogunud Cyrillus Kreeki: "Laulik, kes skandeerib, on harilikult elava loomuga. Laulab hooga, sõnu paukuvalt rõhutades, jalaga õige kõvasti takti lüües, sageli peaga, ehk koguni terve kehaga järsult kaasa õõtsudes. Õõtsumine sünnib [“edasi-tagasi” või vasakule-paremale]. 
Mitteskandeerija on vaikse iseloomuga. Laulu juures ei liiguta kätt ega jalga. Keha kõigub ringi kujuliselt. [---] Skandeerija teab sageli ainult ühte, või kahte viisi, millega ta laulab kõik omad laulud. Helide ümberpaigutamine viisis on võimalik, kuna takt püsib alati muutumatult. Seega variandivaesed laulud. Mitteskandeerijatel samade viiside juures muutub viis õige tublisti (helide ümberpaigutamine ja taktivahetused); sagedasti leidub ühes laulus 3-8 varianti, mis laulu sõnade mõjul tekkinud. Skandeerijatel on nii kindel takt, et isegi sõnade etteütlemisel (ilma laulmata) skandeerivad. Skandeerijaid on suures enamuses. Mitteskandeerijaid leidub mõni üksik." Harald Pauksoni käsitlusest nähtub, et Cyrillus Kreek seab skandeerimise sõltuvusse lauliku temperamendist, Pauksoni materjal näitab pigem, et skandeeriva või mitte-skandeeriva esituse valikus on määrav laululiik. Herbert Tampere (1937) lähtub küsimusest, miks annavad ühe ja sama allika põhjal, kuid erineva suuna meetoditega tehtud tööd vastupidiseid tulemusi ja näitab, et "kabinetiteadlaste" tulemused rajanevad LääneEuroopa normatiivsele poeetikale, mis ei peegelda tekstide elu väljaspool arhiivi (nn loomulikus esitusolukorras). Ta leiab, et on vaja uut lähenemisviisi ja uusi meetodeid, milleks tema pakub eksperimentaalse foneetika ja võrdleva muusikateaduse.

${ }^{10}$ Õieti on tegemist ajaloolaste huviga jutustuslikkuse vastu, ent suulise ajaloo uurija Alessandro Portelli mainib nimelt seost minevikust jutustamise seesmise organiseerituse ja folkloori vahel (Portelli 2000: 66).

\section{Allikad}

EAA.1224.1.156 - Rahvusarhiiv, EELK Lihula kogudus. Personaalraamat 1841-1858.

EKLA f 199 - Eesti Kirjandusmuuseumi Eesti Kultuurilooline Arhiiv, Akadeemilise Ajaloo Seltsi stipendiaatide aruanded (1922-1938).

EKLA f 200 - Eesti Kirjandusmuuseumi Eesti Kultuurilooline Arhiiv, Eesti Kirjanduse Seltsi ajaloo toimkonna stipendiaatide aruanded (1923-1933).

EKLA ÕES - Eesti Kirjandusmuuseumi Eesti Kultuurilooline Arhiiv, Õpetatud Eesti Seltsi kogu (1838-1950).

H II 2 - Eesti Kirjandusmuuseumi Eesti Rahvaluule Arhiiv, Jakob Hurda käsikirjaline rahvaluulekogu: "Vanad laulud. Rahva suust üles tähendanud Jaani kuul 1889 M. Ostrow, studmed., Oskar Kallas, studphil. Märjamaa, Vigala, Karuse, Lihula, Hanila, Hageri".

\section{Kirjandus}

Anderson, Walter 1937. Kettenbriefe in Estland. Eesti Rahvaluule Arhiivi toimetused 7. Tartu: K. Mattiesen.

Anttonen, Pertti 2005. Tradition through Modernity. Postmodernism and the NationState in Folklore Scholarship. Studia Fennica: Folkloristica 15. Helsingi: Finnish Literature Society. 
Apo, Satu 1994. Soome rahvaluule. Laitinen, Kai. Soome kirjanduse ajalugu. Tallinn: Vagabund, lk 17-87.

Bauman, Richard 2012. Performance. Bendix, Regina \& Hasan-Rokem, Galit(toim). A Companion to Folklore. Chichester: Wiley-Blacwell, lk 94-118 (doi: 10.1002/9781118379936. ch5).

Ben-Amos, Dan 2009 [1971]. Folkloori defineerimine konteksti kaudu. Ben-Amos, Dan. Kommunikatsioon ja folkloor. Sator 9. Tartu: Eesti Kirjandusmuuseumi Teaduskirjastus; Eesti Folkloori Instituut, lk 9-26.

Benezer, Gadi 2014 [1999]. Trauma signals in life stories. Rogers, Kim Lacy \& Leydesdorff, Selma \& Dawson, Graham (toim). Trauma and Life Stories: International perspectives. London, New York: Routledge, lk 29-44.

Beyer, Jürgen 2003. Ajalooline jutu-uurimine. Jaago, Tiiu \& Kõresaar, Ene (toim). Pärimus ja tõlgendus. Artikleid folkloristika ja etnoloogia teooria, meetodite ning uurimispraktika alalt. Tartu: Tartu Ülikooli Kirjastus, lk 81-93.

Bronner, Simon J. (toim) 2006. Encyclopedia of American Folklore, Vol. 1-4. London $\&$ New York: Routledge.

Bronner, Simon J. 2016. Toward a Definition of Folklore in Practice. Cultural Analysis 15 (1), lk 6-27 (http://socrates.berkeley.edu/ caforum/volume15/vol15_bronner.html 28. september 2017).

Bronner, Simon J. 2017. Folklore: The Basics. London \& New York: Routledge.

Dundes, Alan 2002 [1977]. Kes on rahvas? Alan Dundes. Kes on rahvas? Valik esseid folkloristikast. Tallinn: Varrak, lk 11-32.

Eesti rahvalaulud 1932 = Eisen, Matthias Johann \& Kallas, Oskar \& Alava, Vihtori \& Anderson, Walter \& Grünthal-Ridala, Villem \& Krohn, Kaarle \& Loorits, Oskar \& Päss, Elmar (toim). Eesti rahvalaulud dr. Jakob Hurda ja teiste kogudest. Teine köide. Eesti Kirjanduse Seltsi toimetused 21. Monumenta Estoniae Antiquae V. Tartu: Eesti Kirjanduse Selts.

Elmer, David 2013. The Milman Parry Collection of Oral Literature. Oral Tradition 28 (2), lk 341-354 (http://journal.oraltradition.org/files/articles/28ii/20_28.2.pdf 9. oktoober 2017).

Finnegan, Ruth 2012 [1970]. Oral Literature in Africa. World Oral Literature Series. Volume 1. United Kingdom, United States: Open Book Publishers (https://archive.org/ details/OralLiteratureInAfrica - 9. oktoober 2017).

Foley, John Miles 1988. The Theory of Oral Composition. History and Methodology. Bloomington, Indianapolis: Indiana University Press.

Frog \& Koski, Kaarina \& Savolainen, Ulla 2016. At the Intersection of Text and Interpretation: An Introduction to Genre. Koski, Kaarina \& Frog \& Savolainen, Ulla (toim). Genre - Text - Interpretation: Multidisciplinary Perspectives on Folklore and Beyond. Studia Fennica: Folkloristica 22. Helsingi: Finnish Literature Society, lk 17-43. 
Gabbert, Lisa 1999. The "Text/Context" Controversy and the Emergence of Behavioral Approaches in Folklore. Folklore Forum 30 (1/2), lk 119-128.

Goody, Jack 2005 [1977]. Metsiku mõtlemise kodustamine. Tallinn: Varrak.

Grele, Ronald J. 1996. Directions for Oral History in the United States. Dunaway, David K. \& Baum, Willa K. (toim). Oral History: An Interdiscilinary Anthology. 2. ed. Walnut Creek, London, New Delhi: Altamira Press, lk 62-84.

Grele, Ronald J. 2007. Reflection on the Practice of Oral History: Retrieving what we can from an earlier Critique. Suomen Antropology 4, lk 11-23 (http://oralhistoryseminar. pbworks.com/w/file/fetch/51790698/Reflections\%20on\%20the\%20Practice\%20of\%20 Oral\%20History.pdf - 9. oktoober 2017).

Grentzstein, Ado 1898. Kirjakogu. Olevik 12.V, nr 19, lk 446 (http://dea.nlib.ee/fullview. php?frameset=3\&showset $=1 \&$ wholepage $=$ keskmine $\&$ pid $=$ s $1227727 \&$ nid $=113419 \& \mathrm{c}$ on $=0-9$. oktoober 2017).

Hasselblatt, Cornelius 2016 [2006]. Eesti kirjanduse ajalugu. Tallinn \& Tartu: Tartu Ülikooli kirjastus.

Heimo, Anne 2010. Kapina Sammatissa. Vuoden 1918 paikalliset tulkinnat osana historian yhteiskunnallisen rakentamisen prosessia. Helsingi: Suomalaisen Kirjallisuuden Seura.

Hermann, Karl August 1898. Eesti kirjanduse ajalugu esimesest algusest meie ajani. Jurjev/Tartu: K. A. Hermann (http://www.digar.ee/arhiiv/et/kollektsioonid/20746 9. oktoober 2017).

Honko, Lauri 1990. Folkloreprosessi. Sananjalka 32, Suomen Kielen Seuran vuosikirja, lk 93-122. [Eesti keeles: Lauri Honko 1998. Folklooriprotsess. Mäetagused 6, lk 56-84, http://www.folklore.ee/tagused/nr6/honko.htm - 9. oktoober 2017, doi: 10.7592/ MT1998.06.honko].

Hoppál, Mihaly 2004. Õnnetoov kettkiri. Kõiva, Mare (toim). Meedia. Folkloor. Mütoloogia. Tänapäeva folkloorist III. Tartu: Eesti Kirjandusmuuseumi rahvausundi töörühma väljaanne, lk 320-338.

Hurt, Jakob 1989. Kõne Eesti vanavara korjamisest muinasaja uurijate kongressil Riias Augusti kuus 1898. Mida rahvamälestustest pidada. Artiklite kogumik. Koostanud Ülo Tedre. Tallinn: Eesti Raamat, lk 75-90.

Hämäläinen, Niina 2017. Emotional Transpositions: Interpreting Oral Lyric Poetry. Folklore: Electronic Journal of Folklore 67, lk 171-198 (doi: 10.7592/FEJF2017.67. hamalainen).

Jaago, Tiiu 1999. Rahvaluule mõiste kujunemine Eestis. Mäetagused 9, lk 70-91 (http:// www.folklore.ee/tagused/nr9/pdf/rhl.pdf-9. oktoober 2017, doi: 10.7592/MT1999.09.rhl).

Jaago, Tiiu 2008. Ruumi kujutamine eluloos: küsimus tõsielujutustuse žanrist. Jaago, Tiiu \& Kõresaar, Ene (toim). Ruumi loomine. Artikleid keskkonna kujutamisest tekstides. Studia Ethnologica et Folklorstica Tartuensia 11. Tartu: Tartu Ülikooli Kirjastus, lk 99-119. 
Jaago, Tiiu 2010. Mälestuste kogumisprotsessis loodud tekstide žanrilisus. 1905. aasta sündmuslugude näitel. Methis 5/6. Omaelulookirjutuse erinumber, lk 159-175 (http:// ojs.utlib.ee/index.php/methis/article/view/526 - 9. oktoober 2017, doi:10.7592/methis. v4i5-6.526).

Jaago, Tiiu 2014. Rahvaluule, ajalugu ja "pärimuslik ajalugu". Keel ja Kirjandus 6, lk 418-435 (http://kjk.eki.ee/ee/issues/2014/6/506 - 9. oktoober 2017).

Jaago, Tiiu 2015. Ann Külm ja Lihula regilaulud. Mandel, Mati (toim). Vana-Läänemaa ajaloo radadel III. Lugusid Lihula kandi minevikust. Lihula: MTÜ Keskaegne Lihula, Vana-Läänemaa Ajaloo Selts, lk 41-54.

Järv, Ants 2001. Esiajaloo rahvakultuurist. Rahvaluule. Annus, Epp \& Epner, Luule \& Järv, Ants \& Olesk, Sirje \& Süvalep, Ele \& Velsker, Mart. Eesti kirjanduslugu. Tallinn: Koolibri, lk 18-22.

Kallas, Oskar 1926. Algsõnaks. Eisen, Matthias Johann \& Kallas, Oskar \& Alava, Vihtori \& Anderson, Walter \& Grünthal-Ridala, Villem \& Krohn, Kaarle \& Loorits, Oskar \& Päss, Elmar (toim). Eesti rahvalaulud dr. Jakob Hurda ja teiste kogudest I. Eesti Kirjanduse Seltsi toimetused 21. Tartu: Tartu Kirjanduse Selts.

Kalmre, Eda 2017. "Jälle uudist, mis on uus ...” Rahvalik ballaad ja jutud Sambla Anust. Keel ja Kirjandus 3, lk 197-210 (http://kjk.eki.ee/ee/issues/2017/3/901 - 9. oktoober 2017).

Kokamägi, Hilja 1957. Mai Kravtsov. Diplomitöö. Tartu: Tartu Riiklik Ülikool, eesti kirjanduse ja rahvaluule kateeder. Käsikiri Tartu Ülikooli eesti ja võrdleva rahvaluule osakonnas, diplomitöö nr 39.

Kreutzwald, Friedrich Reinhold 1861. Sippelgas. Teine jagu. Tartu: H. Laakmann.

Kreutzwald, Friedrich Reinhold 1959. Fr. R. Kreutzwaldi kirjavahetus IV. Tallinn: Eesti Riiklik Kirjastus.

Kurkowska-Budzan, Marta 2014. "Ajaloo tunnistaja” ehk Poola suulise ajaloo spetsiifikast. Mäetagused 56, lk 21-38 (http://www.folklore.ee/tagused/nr56/kurkowska_budzan. pdf - 9. oktoober 2017, doi: 10.7592/MT2014.56.kurkowska_budzan).

Kuutma, Kristin 2010. Mõistete konstrueerimisest teadmuse loomiseni. Keel ja Kirjandus 8-9, lk 687-702 (http://keeljakirjandus.eki.ee/Kuutma\%20687-702.pdf - 9. oktoober 2017).

Kõiva, Mare 1993. Õnnel pole hinda. Kõiva, Mare \& Vissel, Anu (toim). Koolipärimus. Pro Folkloristica I. Tartu: Eesti Kirjandusmuuseum, lk 12-15 (http://www.folklore.ee/ era/nt/PF1/ - 9. oktoober 2017).

Laagus, Aino 2009 [1973]. Situatsioonianalüüsist folkloristikas. Mäetagused 43, lk 113124 (http://www.folklore.ee/tagused/nr43/laagus.pdf - 9. oktoober 2017, doi: 10.7592/ MT2009.43.laagus).

Laugaste, Eduard 1963. Eesti rahvaluuleteaduse ajalugu. Valitud tekste ja pilte. Tallinn: Eesti Riiklik Kirjastus.

Laugaste, Eduard 1970. Alexander Heinrich Neusi osa eesti rahvaluuleteaduse ajaloos. Tartu Riikliku Ülikooli toimetised 259. Tartu: Tartu Riiklik Ülikool, lk 95-146. 
Laugaste, Eduard 1986. Eesti rahvaluule. 3. parandatud ja täiendatud trükk. Tallinn: Valgus.

Lawson, Francesca R. Sborgi 2010. Rethinking the Orality-Literacy Paradigm in Musicology. Oral Tradition 25 (2), lk 429-446 (http://journal.oraltradition.org/issues/25ii/ lawson -9. oktoober 2017).

Liljewall, Britt 2013. Recollections of Reading and Writing. Another Picture of Swedish Literacy. Kusmin, Anna \& Driscoll, M. J. (toim). White Field, Black Seeds. Nordic Literacy Practices in the Long Nineteenth Century. Studia Fennica: Litteraria 7. Helsingi: Finnish Literature Society, lk 30-39.

Lintrop, Aado 2016. Loomisaja laulud. Uurimusi eesti rahvalaulust. Eesti Rahvaluule Arhiivi toimetused. Commentationes Archivi Traditionum Popularium Estoniae 35. Tartu: Eesti Kirjandusmuuseumi Teaduskirjastus.

Lord, Albert B. 1997 [1960]. The Singer of Tales. Cambridge, Massachusetts, London: Harvard University Press.

Lorenz, Chris 2013. Ajalugu ja teooria. Tuna. Ajalookultuuri Ajakiri 4 (61), lk 94-107. Mulholland, James 2009. James Macpherson's Ossian Poems, Oral Traditions, and Invention of Voice. Oral Tradition 24 (2), lk 393-414 (http://journal.oraltradition.org/ issues/24ii/mulholland - 9. oktoober 2017).

Mundal, Else \& Wellendorf, Jonas (toim) 2008. Oral Art Forms and their Passage into Writing. Kopenhaagen: Museum Tusculanum Press.

Mälk, Vaina 1963. Eesti Kirjameeste Seltsi osa eesti folkloristika arengus. Tallinn: Eesti Riiklik Kirjastus.

Neus, Alexander Heinrich 1850. Ehstnische Volkslieder. Urschrift und Uebersetzung I. Reval: Kluge und Ströhm.

Nõmmela, Marleen 2007. Etnograafiks kujunemine: Gustav Ränga välitööpraktika 1920. aastatel. Studia Ethnologica et Folkloristica Tartuensia 10. Tartu: Tartu Ülikooli Kirjastus.

Org, Andrus 2017. Eesti ulmekirjanduse žanrid ja nende poeetika. Dissertationes Litterarum et Contemplationis Comparativae Universitas Tartuensis 16. Tartu: Tartu Ülikooli Kirjastus.

Paukson, Harald 1930. Meie rahvalaulu ettekande-rütmist. Looming 4, lk 433-448.

Paškevica, Beata 2016. Läti rahvalaulud Johann Gottfried Herderi kogus. Mäetagused 65, lk 55-66 (http://www.folklore.ee/tagused/nr65/pashkevica.pdf - 9. oktoober 2017, doi: 10.7592/MT2016.65.pashkevica).

Portelli, Alessandro 2000 [1979]. What makes oral history different. Berks, Robert \& Thomson, Alistair (toim). The Oral History Reader. London, New York: Routledge, lk 63-74.

Pöysä, Jyrki 2009. Kogumisvõistlused pärimusliku ajaloo uurimises. Mäetagused 43, lk 39-60 (http://www.folklore.ee/tagused/nr43/poysa.pdf - 9. oktoober 2017, doi: 10.7592/ MT2009.43.poysa). 
Quick, Catherine S. 1999. Ethnopoetics. Folklore Forum 30 (1/2), lk 95-105.

Roll, Tiiu 1992. Regilaulu poeetika käsitlusi Eestis 19. sajandil. Järv, Ants \& Merilai, Arne \& Roll, Tiiu (toim). Eesti rahvaluule käsitlusi. Töid eesti filoloogia alalt. Tartu Ülikooli toimetised 943. Tartu: Tartu Ülikool, lk 45-60.

Rosenplänter, Johann Heinrich 1818. Beiträge zur genauern Kenntniss der ehstnischen Sprache XI. Pernau, Reval, Riga Dorpat: [Rosenplänter], Bornwasser, Hartmann. Meinshausen.

Rüütel, Ingrid 1987. Folkloor ja tänapäeva kultuur. Kultuur ja Elu 5-6, lk 11-15, 18-22.

Saarlo, Liina 2005. Eesti regilaulude stereotüüpiast. Teooria, meetodid ja tähendus. Dissertationes Folkloristicae Universitatis Tartuensis 5. Tartu: Tartu Ülikooli Kirjastus (http://dspace.ut.ee/bitstream/handle/10062/838/saarlo.pdf;jsessionid=9FC691BFBFD5 B56298BAD1E2D7B92566? sequence=5 - 10. oktoober 2017).

Sander, Tõnu 1899. Eesti kirjanduse ajalugu. I jagu. Rahvaluule. Jurjev (Tartu): K. Sööt.

Savolainen, Ulla 2016. The Genre of Reminiscence Writing. Koski, Kaarina \& Frog \& Savolainen, Ulla (toim). Genre - Text - Interpretation: Multidisciplinary Perspectives on Folklore and Beyond. Studia Fennica: Folkloristica 22. Helsingi: Finnish Literature Society, lk 203-231.

Schröder, Mai 2003. Jätnud jälje Hanila ja Karuse kultuurilukku. Vesker, Laine (toim). Viljariik. Hanila ja Karuse ajalooradadel II. Hanila: Hanila Muuseumi Selts, August Tampärgi nimeline Hanila Muuseum, lk 54-73.

Seljamaa, Elo-Hanna 2005. Kettkirjadest folkloristikat ja folkloriste otsimas. Hiiemäe, Mall \& Labi, Kanni (toim). Aega otsimas. Pro Folkloristica XII. Tartu: Eesti Kirjandusmuuseum, lk 139-150.

Tampere, Herbert 1937. Eesti vana rahvalaulu rütmiprobleemidest. Looming 2, lk 190198.

Tedre, Ülo 1998. Rahvaluule. Viires, Ants \& Vunder, Elle (toim). Eesti rahvakultuur. Tallinn: Eesti Entsüklopeediakirjastus, lk 545-587.

Tedre, Ülo 2003. Eesti mees ja tema sugu XIX sajandi Eesti lõppriimilises rahvalaulus. Tallinn \& Tartu: Eesti Kirjandusmuuseum.

Thomson, Alistair 2007. Eine Reise durch das Gedächtnis unserer Bewegung: Vier paradigmatische Revolutionen in der Oral History. BIOS: Zeitschrift für Biographieforschung, Oral History und Lebensverlaufsanalysen. Sonderheft. 20. Jg., lk 21-29.

Toomeos-Orglaan, Kärri 2015. Mida setod lugesid? "Kirjaoskamatud” setod kirjakultuuri mõjuväljas. Keel ja Kirjandus 8-9, lk 603-622 (http://kjk.eki.ee/ee/issues/2015/8-9/685. 10. oktoober 2017).

Vahtramäe, Ell 2003. Rahvajutud ja raamatujutud. Suulise ja kirjaliku kultuuri lõikumiskoht kui väljakutse folkloristikale. Jaago, Tiiu \& Kõresaar, Ene (toim). Pärimus ja tõlgendus. Artikleid folkloristika ja etnoloogia teooria, meetodite ning uurimispraktika alalt. Tartu: Tartu Ülikooli Kirjastus, lk 104-116. 
Valk, Ülo 2005a. Mis on rahvaluule? Valk, Ülo \& Metsvahi, Merili (koost). Regivärsist netinaljadeni. Sissejuhatus rahvaluulesse. Tallinn: Koolibri, lk 9-12.

Valk, Ülo 2005b. Establishment of the Estonian Folklore Collections and the Concept of Authenticity. Schmitt, Christoph (toim). Volkskundliche Großprojekte. Ihre Geschichte und Zukunft. Rostocker Beiträge zur Volkskunde und Kulturgeschichte. Münster, New York, München, Berlin: Waxmann Verlag GmbH, lk 33-38.

Valk, Ülo 2015. Kui muistendist saab fiktsioon. Keel ja Kirjandus 8-9, lk 541-555 (http:// kjk.eki.ee/ee/issues/2015/8-9/681 - 10. oktoober 2017).

Võsu, Ester 2008. Etendus/esitus. Jaago, Tiiu (toim). Argikultuuri uurimise terminoloogia e-sõnastik. Tartu: Tartu Ülikool, eesti ja võrdleva rahvaluule osakond (http:// argikultuur.ut.ee - 10. oktoober 2017).

Webster, Anthony K \& Kroskrity, Paul V. 2013. Introducing Ethnnopoetics: Hymes's Legacy. Journal of Folklore Research 50 (1-3), lk 1-10 (doi: 10.2979/jfolkrese.50.1-3.1).

\section{Summary}

\section{Orality in the era of written culture}

\section{Tiiu Jaago}

Assistant Professor

Department of Estonian and Comparative Folklore

Institute of Cultural Research, University of Tartu

tiiu.jaago@ut.ee

Keywords: folklore, oral and written in folklore research, oral history, oral literature

The article focuses on the question of the orality and literacy of folklore on the example of Estonian folklore research. When folklore is defined in academic and popular-science papers, its orality has a significantly more prominent role than in practical studies. For instance, in the period when folkloristic standpoints were modernised in the $1930 \mathrm{~s}$, orality was a requisite in the definition of folklore. At the same time, folklorists also studied the written forms of folklore (e.g. works by Walter Anderson). When assessing the authenticity of earlier folk songs and tales, the decisive aspect was the oral origin and spread of the texts. However, older folk songs as well as folk tales were mostly written down in the era when the performers of these songs or tales were literate. It was common that newer folk songs spread in writing, but researchers nevertheless used them to the same extent as archival texts that had been written down based on oral performance. They argued that the texts which were spread in manuscript songbooks could also be performed orally, and this justified their treatment as folklore even though they were written texts.

In parallel with the development of folkloristics, the question of the relationships of folklore and literature and folklore and (oral) history has continuously been on the agenda. In both cases, folklore opens up from the viewpoint of written culture. The 
topic of the orality and literacy of folklore also emerges in connection with the recording of oral performances, as well as creating and organising archives of manuscripts. It similarly extends to research: written records of oral presentations were analysed, using the methods for the analysis of written texts.

In the second half of the 20th century, however, the question of the orality of oral sources was increasingly raised. In these cases, orality is important from the aspect of performance and the creative process, differently from the earlier notion, which saw the oral creation, origin, and spread as the prerequisite of folklore. It is also significant that orality studies are interdisciplinary (involving, for example, the research methods of linguistics, anthropology, history, etc.). 